\title{
Seleksi Pendonor Serbuk Sari Sifat Kuantitas Endosperma Skor Tinggi pada Kelapa Dalam Kopyor
}

\section{Selection of Pollen Contributor for High Endosperm Quantity Character in Kopyor Tall Coconut}

\author{
Megayani Sri Rahayu ${ }^{1,2}$, Asep Setiawan², Ismail Maskromo³, Agus Purwito², dan Sudarsono ${ }^{2 *}$ \\ ${ }^{1}$ Program Studi Pemuliaan dan Bioteknologi Tanaman, Sekolah Pascasarjana, Institut Pertanian Bogor \\ ${ }^{2}$ Departemen Agronomi dan Hortikultura, Fakultas Pertanian, Institut Pertanian Bogor \\ (Bogor Agricultural University), Jl. Meranti, Kampus IPB Darmaga, Bogor 16680, Indonesia \\ ${ }^{2}$ Balai Penelitian Kelapa (Balitka), Badan Penelitian dan Pengembangan Pertanian \\ (Balitbangtan), Jl. Mapanget, Manado 95001, Indonesia
}

Diterima 20 April 2018/Disetujui 19 Desember 2018

\begin{abstract}
Endosperm quantity in kopyor coconut determines the quality of kopyor coconut. However, data of the best parental based on their progeny test is unavailable yet. In this study, we employed polycross approach and SSR molecular marker to estimate general combining ability of the best pollen contributor for the breeding purpose of this trait. Totally 151 kopyor coconuts were collected from the naturally open-pollinated population of kopyor Tall coconut Agom Lampung. The harvested nuts were rated for their endosperm quantity (scored 1-9). The analysis identified 31 paternal trees of the 53 progenies. The TJ-185 with the highest GCA has been considered as a promising paternal tree for development of high endosperm quantity of kopyor coconut.
\end{abstract}

Keywords: combining ability, molecular marker, paternal trees, polycross, tall coconut

\section{ABSTRAK}

Kuantitas endosperma kelapa kopyor menentukan kualitas dari buah kopyor, namun hingga saat ini belum ada informasi tentang tetua persilangan terbaik untuk sifat kuantitas endosperma. Penelitian ini menggunakan pendekatan polycross dan analisis tetua jantan berbasis marka molekular SSR untuk mengidentifikasi tetua jantan dan menduga nilai daya gabung umum sifat kuantitas endosperma kelapa kopyor. Sebanyak 151 buah kelapa kopyor dipanen dari populasi kelapa Dalam kopyor Agom Lampung yang menyerbuk silang secara alami. Buah yang dipanen diberi skor untuk sifat kuantitas endosperma (skor 1-9). Analisis tetua jantan berhasil mengidentifikasi 31 tetua jantan dari 53 progeni. Tetua jantan TJ-185 yang memiliki nilai daya gabung umum tertinggi dipertimbangkan sebagai tetua jantan terpilih untuk pengembangan kelapa kopyor dengan skor kuantitas endosperma tinggi.

Kata kunci: analisis tetua jantan, daya gabung, kelapa dalam, marka molekuler, polycross

\section{PENDAHULUAN}

Buah kelapa kopyor adalah buah dari kelapa (Cocos nucifera) mutan alami yang banyak diminati masyarakat Indonesia (Sudarsono, 2017; Sudarsono et al., 2015). Terdapat dua tipe kelapa kopyor di Indonesia, yaitu kelapa Genjah kopyor dan kelapa Dalam kopyor (Maskromo et al., 2013; Maskromo et al., 2012a; 2012b). Endospermanya merupakan bahan baku untuk minuman penyegar yang memiliki rasa lezat yang khas (Maskromo, 2015; Sudarsono, 2017; Sudarsono et al., 2015). Perbedaan utama antara endosperma kelapa kopyor dan kelapa normal terletak pada

\footnotetext{
* Penulis untuk korespondensi. e-mail: s_sudarsono@ymail.com
}

struktur dan tekstur endospermanya (Maskromo, 2015; Sudarsono et al., 2015; Sudarsono, 2017). Perbedaan ini menyebabkan endosperma kelapa kopyor memiliki rasa unik dan lebih lembut dibandingkan dengan rasa endosperma kelapa normal. Kelapa kopyor dikonsumsi masyarakat sebagai makanan dan minuman penyegar, serta sebagai bahan baku es krim (Maskromo et al., 2015).

Endosperma buah kelapa normal yang sudah masak memiliki struktur padat yang keras dengan ketebalan sekitar 0.5-1.0 cm (Kumar et al., 2015), sementara endosperma kelapa kopyor bersifat lunak dan terlepas dari batoknya (Maskromo et al., 2014). Sifat buah kopyor diwariskan secara genetik dari tetua kepada progeninya. Kelapa mutan alami yang dikenal dengan nama Makapuno ditemukan di Filipina. Struktur dan tekstur endosperma Makapuno 
berbeda dari kelapa kopyor. Endosperma kelapa kopyor jika tua bentuknya remah sedangkan endosperma kelapa Makapuno membentuk struktur seperti cairan pelumas (Maskromo et al., 2014). Perbedaan pada level molekuler antara endosperma Makapuno dan endosperma kelapa normal salah satunya adalah endosperma Makapuno memiliki miRNA terekspresi lebih tinggi (176 miRNA) dibandingkan endosperma kelapa normal muda yang memiliki 95 miRNA (Li et al., 2009). Sejumlah gen yang berasal dari kelapa kopyor telah diisolasi dan diidentifikasi tetapi masih belum dapat dipastikan hubungannya dengan sifat endosperma kopyor pada kelapa (Sukendah et al., 2017; Sukendah et al., 2011).

Tingkat terkelupasnya endosperma pada buah kelapa kopyor bervariasi. Ada buah kopyor yang endospermanya sangat terkelupas atau terkelupas semua dari batok namun ada juga yang tingkat terkelupasnya rendah. Kelapa kopyor dengan tingkat terkelupas endosperma yang tinggi lebih disukai masyarakat. Tingkat terkelupasnya endosperma dikenal dengan istilah 'kuantitas endosperma', yang dapat dikategorikan ke dalam nilai skor 1 sampai 9 (Sudarsono et al., 2011; Maskromo et al., 2014). Skor 1 menggambarkan kondisi endosperma yang masih melekat pada batok kelapa (Sudarsono et al., 2011; Maskromo et al., 2014), sedangkan skor 9 menggambarkan endosperma yang seluruhnya sudah terkelupas dari batok kelapa. Maskromo (2015) dan Maskromo et al. (2016) menduga efek xenia cukup berperan mengendalikan sifat kuantitas endosperma pada kelapa. Xenia oleh Olfati et al. (2010) didefinisikan sebagai fenomena pengaruh serbuk sari terhadap perkembangan buah dan biji.

Desa Agom Jaya, Kecamatan Kalianda, Kabupaten Lampung Selatan sudah lama dikenal sebagai penghasil kelapa kopyor. Kelapa kopyor yang tumbuh di desa Agom Jaya termasuk tipe kelapa Dalam (Maskromo et al., 2012a; 2012b). Kelapa Dalam memiliki ciri pola penyerbukan silang (Pandin, 2009). Persebaran serbuk sari sebagai akibat penyerbukan silang pada kelapa kopyor dapat mencapai jarak sejauh $63 \mathrm{~m}$ seperti yang dilaporkan Larekeng et al. (2015a; 2015b). Tinggi tanaman kelapa kopyor di Agom, Lampung dapat mencapai $30 \mathrm{~m}$ dan perlu waktu sekitar lima tahun untuk menghasilkan buah pertamanya. Kondisi ini menyebabkan penerapan persilangan terkendali untuk mengkaji kendali genetik suatu sifat tertentu secara teknis sulit dilakukan. Kesulitan mengumpulkan serbuk sari, proses kastrasi, dan penyerbukan dapat menyebabkan terjadinya peluang yang tinggi terhadap kontaminasi serbuk sari, terbatasnya jumlah kombinasi persilangan, maupun jumlah progeni pada setiap kombinasi persilangan. Pendekatan polycross dengan penyerbukan secara alami menjadi pilihan yang disukai, meskipun pendekatan ini memiliki kekurangan yaitu tidak diketahuinya tetua donor serbuk sari.

Sejumlah marka molekuler seperti simple sequence repeat (SSR) atau single nucleotide amplified polymorphism (SNAP) telah digunakan untuk mengevaluasi keragaman genetik kelapa (Maskromo, 2015; Pesik et al., 2017; Pesik et al., 2015). Pelacakan tetua populasi kelapa Dalam Mapanget (Pandin et al., 2008) dan sifat tandan buah pada sawit (Yono et al., 2017) mengindikasikan bahwa marka molekuler SSR merupakan marka molekuler yang efektif untuk mendukung pemuliaan tanaman tahunan seperti kelapa. Marka SSR telah banyak digunakan untuk studi keragaman genetik maupun identifikasi hibrida dan progeni kelapa (Martinez et al., 2010; Perera et al., 2010; Pesik et al., 2015; Ribeiro et al., 2010; Yao et al., 2013), namun pemanfaatan marka molekuler SSR untuk identifikasi tetua kelapa kopyor dengan sifat kuantitas endosperma tinggi belum pernah dilakukan.

Minimnya kajian genetik sifat kuantitas endosperma kelapa, sulitnya melakukan studi persilangan terkontrol pada kelapa tipe Dalam, dan tersedianya marka molekuler SSR yang bersifat kodominan menjadi latar belakang dilakukan penelitian ini. Identifikasi tanaman sebagai tetua persilangan dalam pengembangan kelapa kopyor unggul yang memiliki sifat kuantitas endosperma tinggi belum pernah dilakukan sebelumnya. Penelitian ini bertujuan menilai tingkat keragaman genetik kebun kelapa Agom Lampung, membuktikan efektivitas analisis tetua jantan (paternal analysis) berbasis marka molekuler SSR dalam mengidentifikasi donor serbuk sari dan mengidentifikasi tetua jantan terbaik untuk sifat kuantitas endosperma pada populasi alami kelapa Dalam kopyor.

\section{BAHAN DAN METODE}

\section{Bahan Tanaman untuk Penelitian}

Penelitian dilakukan di kebun kelapa kopyor milik petani di desa Agom Jaya, Kecamatan Kalianda, Kabupaten Lampung Selatan, Provinsi Lampung (GPS position: S 539.478 E 105 34.978). Buah yang dipanen merupakan hasil polycross (penyerbukan terbuka) yang terjadi secara alami tanpa campur tangan manusia. Seluruh pohon kelapa di area penelitian adalah pohon kelapa kopyor heterozigot yang telah didata dan diberi nomor urut. Sebanyak 151 buah kelapa kopyor yang dihasilkan dari 125 pohon dipanen secara bertahap di kebun kelapa kopyor milik petani selama 22 bulan periode pelaksanaan penelitian yaitu pada bulan Januari 2015 hingga bulan November 2016. Setiap buah kelapa yang dipanen diberi nomor sesuai dengan nomor identitas pohon induk yang tertulis di batang pohon induk. Selain buahnya, daun kelapa dewasa juga diambil sebagai sampel pengamatan. Jika dari satu pohon induk betina dipanen lebih dari satu buah, maka setiap buah diberi huruf index, seperti kode $5 \mathrm{a}$ dan 5 b yang mengindikasikan kedua buah dipanen dari pohon induk no. 5. Buah dipanen oleh pemanjat profesional yang telah terampil mengenali ciriciri buah kelapa kopyor dengan cara mengetuk-ngetuk buah kelapa tersebut sehingga terdengar suara khas dari dalam buah kelapa sebelum buah tersebut dipanen. Pohon kandidat tetua jantan maupun pohon induk adalah kelapa kopyor heterozigot yang semuanya dapat menghasilkan buah kopyor dan buah normal dengan rasio 1:3.

Buah kelapa kopyor yang telah dipanen, dikirim ke Laboratorium Plant Molecular Biology (PMB), Departemen Agronomi dan Hortikultura, Fakultas 
Pertanian IPB, Bogor untuk dilakukan pengukuran karakter fisik buah dan skoring kuantitas endosperma. Sabut buah kelapa dikupas, untuk selanjutnya buah kelapa tanpa sabut dibelah menjadi dua bagian. Batok kelapa yang terbelah serta terlihat endospermanya difoto menggunakan kamera digital. Kuantitas endosperma diberi nilai skor dengan cara membandingkan hasil foto dengan foto standar skoring kuantitas endosperma (Maskromo et al., 2014; Sudarsono et al., 2011). Visualisasi endosperma buah kelapa normal dan kelapa kopyor dapat dilihat pada Gambar 1.

\section{Ekstraksi DNA dan Analisis SSR}

Ekstraksi DNA menggunakan metode CTAB (Rohde et al., 1995), yang secara rutin telah digunakan untuk isolasi DNA dari berbagai tanaman palma di Indonesia (Ajambang et al., 2012; Budiman et al., 2019; Natawijaya et al., 2019; and Tinche et al., 2014). Total DNA populasi tanaman dewasa diisolasi dari jaringan daun muda. Sebaliknya untuk total DNA populasi progeni diisolasi dari jaringan embrio zigotik.

Analisis SSR dilakukan dengan menggunakan 10 primer SSR yang bersifat polimorfik yang dikembangkan oleh Lebrun et al. (2001), yaitu Cn Cir B12, Cn Cit 56, Cn Cir 81, Cn Cir 86, Cn Cir 87, Cn Cir 123, Cn Cir 147, Cn Cir 206, CnZ 18, CnZ 51. Amplifikasi pita DNA dilakukan menggunakan mesin Polymerase Chain Reaction (PCR) dengan Kapa $2 G$ Fast Polymerase ${ }^{\mathrm{TM}}$ PCR Kit (KAPA Biosystems Inc. USA), jumlah siklus 35, suhu denaturasi (94 ${ }^{\circ} \mathrm{C}$; 30 detik), anealing $\left(48-60{ }^{\circ} \mathrm{C} ; 15\right.$ detik) dan extension $\left(72^{\circ} \mathrm{C}\right.$; awal 5 detik; akhir 10 menit). Pemisahan produk amplifikasi dilakukan dengan Polyacrilamide Gel Electrophoresis (PAGE) tipe vertical selama 30 menit dengan kuat arus $100 \mathrm{~mA}$ dan voltase 210 volt. Gel yang digunakan adalah $6 \%$ polyacrilamide gel dalam larutan penyangga SB 1x (Brody and Kern, 2004). Visualisasi hasil elektroforesis vertikal dilakukan menggunakan silver staining (Creste et al., 2001). Ukuran produk amplifikasi diduga dengan menggunakan 100 bp DNA ladders. Pita-pita DNA hasil amplifikasi PCR (amplicon) yg telah dielektroforesis dan diwarnai dengan silver staining diberi skor 0 jika tidak terbentuk amplicon. Sebaliknya, jika didapatkan amplikon, maka amplicon yang didapat dari seluruh individu dalam populasi yg dianalisis diberi nomor secara berurutan sesuai dengan ukurannya (amplicon yang terkecil diberi no. 1, dan seterusnya hingga amplicon yang terbesar).

\section{Analisis Tetua Jantan}

Progeni dinyatakan sebagai hibrida hasil persilangan apabila mewarisi alel spesifik yang dimiliki oleh kedua tetuanya. Jika progeni hanya mewarisi alel dari tetua induk betina maka dikategorikan sebagai progeni hasil penyerbukan sendiri. Progeni yang memiliki satu alel dari tetua induk betina dan satu alel yang asalnya bukan dari individu calon tetua jantan dalam populasi persilangan diduga sebagai tipe simpang yang tetua jantannya dari luar populasi persilangan. Progeni seperti ini tidak digunakan dalam analisis lebih lanjut.

Identitas tetua jantan dari masing-masing individu progeni ditentukan berdasarkan hasil analisis parentage berbasis multiple loci data hasil genotyping dengan marka SSR. Analisis parentage dilakukan menggunakan perangkat lunak CERVUS versi 3.0.7 (Kalinowski et al., 2007). Parameter yang digunakan dalam analisis adalah bootstrap 1000x dan threshold dengan tingkat kepercayaan penentuan tetua $80 \%$ (relax) dan $95 \%$ (strick).

\section{HASIL DAN PEMBAHASAN}

\section{Analisis SSR Populasi Kelapa Agom Lampung}

Kesepuluh primer yang digunakan bersifat polimorfik karena sudah dilakukan penapisan primer-primer sebelum digunakan. Contoh hasil analisis parentage dari progeni F140b yang dipanen dari tetua betina TB-40, teridentifikasi mempunyai tetua jantan TJ-185. Berdasarkan genotyping menggunakan lokus marka SSR CnCIR_87, genotipe tetua betina TB-40 dan progeni F1-40b adalah homosigot 11, sedangkan tetua jantan TJ-185 adalah heterosigot 12 .
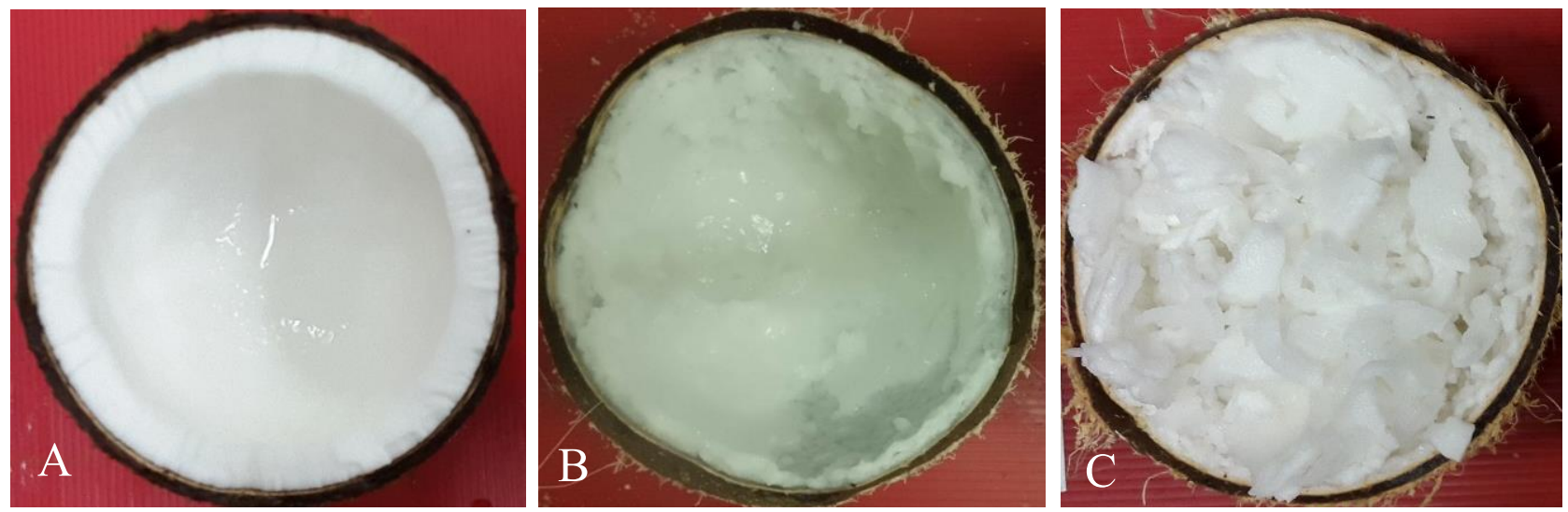

Gambar 1. Endosperma buah kelapa; (A) kelapa normal, (B) kelapa kopyor skor rendah, (C) kelapa kopyor skor tinggi 
Dengan demikian, tetua jantan TB-213 (TJ185 dan tetua betina TB-40 masing-masing berkontribusi alel 1 sehingga menghasilkan progeni F1-40b dengan genotipe homosigot 11 (Gambar 2A). Dengan analogi yang sama, tetua betina TB-213 (heterosigot 12) dan tetua jantan TJ185 (heterosigot 12) masing-masing berkontribusi alel 1 atau alel 2 sehingga menghasilkan progeni F1-213b dengan genotipe heterosigot 12 (Gambar 2.B).

Berdasarkan analisis frekuensi alel, diperoleh nilai proporsi heterozigositas yang tinggi pada populasi kelapa Dalam Agom Lampung yaitu $\mathrm{Ho}=57 \%$ dan $\mathrm{He}=67 \%$. Nilai ini menggambarkan populasi kelapa Dalam Agom Lampung merupakan populasi menyerbuk terbuka yang memiliki keragaman tinggi. Nilai Ho populasi kelapa kopyor Agom lampung lebih tinggi dibandingkan nilai heterozigositas koleksi kelapa Dalam asal Asia Tenggara (53.0\%), kelapa Dalam asal Panama (23.0\%), dan kelapa Genjah asal Asia Tenggara (9.90 \%) seperti yang dilaporkan oleh Gunn et al. (2011). Hasil analisis ini memperkuat pernyataan sebelumnya bahwa populasi pohon kelapa Agom Lampung merupakan populasi menyerbuk silang dan tingkat heterozigositasnya masih terjaga dengan baik. Hasil tersebut juga mengindikasikan bahwa populasi kelapa Dalam Agom Lampung merupakan sumber plasma nutfah penting bagi upaya pengembangan kelapa Dalam kopyor.

\section{Analisis Tetua Jantan (Paternal Analysis)}

Paternal analysis pada penelitian ini dilakukan dengan melibatkan 276 data, meliputi 125 data SSR DNA tetua yang diambil dari daun pohon dewasa dan 151 data SSR DNA progeni yang diambil dari embrio zigotik. Pada taraf kepercayaan 85\% (relax setting), diperoleh 31 kandidat dari 125 kandidat donor serbuk sari (24.8\%) teridentifikasi positif sebagai donor serbuk sari untuk 53 individu progeni.

Hasil analisis menunjukkan bahwa jumlah progeni yang didapatkan dari tetua jantan berkisar antara 1 hingga 5. Sebanyak 19 donor serbuk sari teridentifikasi hanya menghasilkan 1 progeni. Donor serbuk sari TJ-130, TJ15, TJ-179, TJ-180, TJ-203, TJ-206, dan TJ-208 masingmasing berkontribusi menghasilkan 2 progeni (Tabel 1). Donor serbuk sari TJ-185 masing-masing berkontribusi menghasilkan 3 progeni; donor serbuk sari TJ-198, TJ-181, dan TJ-202 masing-masing berkontribusi menghasilkan 4 progeni; dan donor serbuk sari TJ-197 berkontribusi menghasilkan 5 progeni (Tabel 2).

Sulitnya melaksanakan emaskulasi, pengumpulan serbuk sari serta pelaksanaan penyerbukan terkontrol menyebabkan pendekatan polycross menjadi salah satu pendekatan yang banyak dipilih, walaupun pendekatan ini memiliki kelemahan yaitu hilangnya informasi tetua jantan (Tew and Pan, 2010). Metode paternal analysis yang berbasis marka molekuler SSR memberikan hasil bahwa informasi tetua jantan sebagai donor serbuk sari berhasil didentifikasi (Tabel 1 dan 2). Penelitian penggunaan paternal analisis untuk mengidentifikasi tetua jantan yang menyumbang serbuk sari dalam pembentukan buah kelapa telah dilaporkan oleh Laerekeng et al. (2015a, 2015b) dan Maskromo et al. (2016).

Identifikasi tetua terpilih untuk sifat kuantitas endosperma dapat didasarkan pada hasil uji progeni buah kelapa F1 tanpa harus menunggu tumbuhnya tanaman dan buah F2. Identifikasi ini dapat dimungkinkan karena karakter kuantitas endosperma dapat muncul akibat adanya efek xenia, yaitu efek dari gen pengendali sifat kuantitas endosperma terhadap fenotipenya dapat langsung dilihat dan diamati pada endosperma buah kelapa F1.

Kegiatan seleksi pohon kelapa dilakukan untuk mendapatkan pohon induk terbaik untuk tujuan produksi atau sebagai tetua persilangan untuk perakitan varietas unggul baru. Pemilihan tetua umumnya didasarkan pada nilai daya gabung tetua persilangan yang dinilai dari hasil uji progeni. Acquaah (2012) mendefinisikan daya gabung umum sebagai selisih antara rata-rata performa suatu genotipe tertentu dengan rata-rata performa umum.
Lokus SSR CnCir_87

TB-40

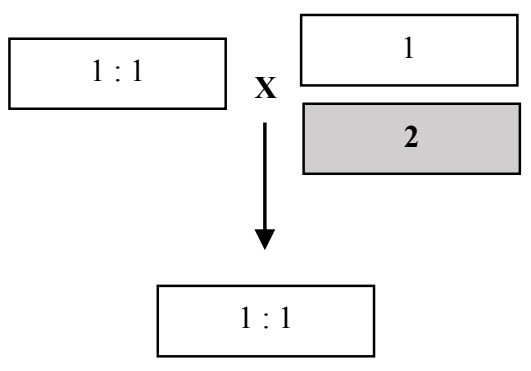

$\mathrm{F}_{1}-40 \mathrm{~b}$

(A)
Lokus SSR CnCir_87

TB-213

TJ-185

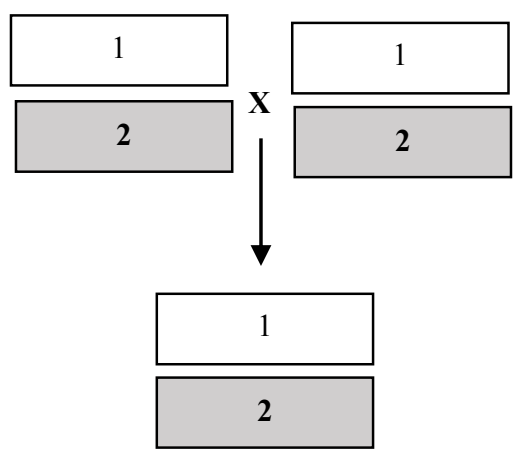

$\mathrm{F}_{1}-213 \mathrm{~b}$

(B)

Gambar 2. Skematik segregasi alel SSR; (A) segregasi pada lokus CnCir_87 persilangan TB-40 x TJ-185, (B) segregasi pada lokus CnCir_87 persilangan TB-213 x TJ-185 
Rahayu et al. / J. Agron. Indonesia 47(1):97-104

Tabel 1. Identitas keturunan, induk, dan kandidat tetua jantan yang menghasilkan 2 progeni

\begin{tabular}{|c|c|c|c|c|c|}
\hline \multirow{2}{*}{ No } & \multirow{2}{*}{ ID Keturunan } & \multicolumn{3}{|c|}{ Tetua jantan yang menghasilkan 2 progeni } & \multirow{2}{*}{ Trio confidence } \\
\hline & & ID Induk & ID Kandidat tetua jantan & Trio LOD score & \\
\hline \multirow[t]{2}{*}{1} & F1-121a & TB-121 & TJ-130 & $2.26 \mathrm{E}+0$ & + \\
\hline & F1-221c & TB-221 & TJ-130 & $-4.05 \mathrm{E}-1$ & + \\
\hline \multirow[t]{2}{*}{2} & F1-120a & TB-120 & TJ-15 & $6.83 \mathrm{E}+0$ & $*$ \\
\hline & $\mathrm{F} 1-185 \mathrm{~b}$ & TB-185 & TJ-15 & $3.76 \mathrm{E}+0$ & + \\
\hline \multirow[t]{2}{*}{3} & F1-203a & TB-203 & TJ-179 & $3.40 \mathrm{E}+0$ & + \\
\hline & F1-221a & TB-221 & TJ-179 & $2.35 \mathrm{E}+0$ & + \\
\hline \multirow[t]{2}{*}{4} & F1-60a & TB-60 & TJ-180 & $2.27 \mathrm{E}+0$ & + \\
\hline & F1-82f & TB-82 & TJ-180 & $4.47 \mathrm{E}+0$ & + \\
\hline \multirow[t]{2}{*}{5} & $\mathrm{~F} 1-48 \mathrm{a}$ & TB-48 & TJ-203 & $4.17 \mathrm{E}+0$ & + \\
\hline & F1-88a & TB-88 & TJ-203 & $2.77 \mathrm{E}+0$ & + \\
\hline \multirow[t]{2}{*}{6} & F1-88d & TB-88 & TJ-206 & $7.61 \mathrm{E}-1$ & + \\
\hline & F1-194c & TB-194 & TJ-206 & $3.55 \mathrm{E}+0$ & + \\
\hline \multirow[t]{2}{*}{7} & $\mathrm{~F} 1-79 \mathrm{~b}$ & ТВ-79 & TJ-208 & $2.74 \mathrm{E}+0$ & + \\
\hline & F1-185a & TB-185 & TJ-208 & $4.89 \mathrm{E}+0$ & + \\
\hline
\end{tabular}

Keterangan: $\mathrm{TB}=$ tetua betina; $\mathrm{TJ}=$ tetua jantan; $\mathrm{ID}=$ identitas; $*=$ sangat nyata pada taraf $95 \% ;+=$ nyata pada taraf $85 \%$

Tabel 2. Identitas keturunan dan kandidat tetua jantan yang menghasilkan 3, 4, dan 5 progeni

\begin{tabular}{|c|c|c|c|c|c|}
\hline \multirow{2}{*}{ No } & \multirow{2}{*}{ ID Keturunan } & \multicolumn{3}{|c|}{ Tetua jantan yang menghasilkan 3 progeni } & \multirow{2}{*}{ Trio confidence } \\
\hline & & ID Induk & ID Kandidat tetua jantan & Trio LOD score & \\
\hline \multirow[t]{3}{*}{1} & F1-40b & TB-40 & TJ-185 & $5.03 \mathrm{E}-1$ & + \\
\hline & F1-197f & TB-197 & TJ-185 & $2.48 \mathrm{E}+0$ & + \\
\hline & F1-213a & TB-213 & TJ-185 & $-7.23 \mathrm{E}-1$ & + \\
\hline \multicolumn{6}{|c|}{ Tetua jantan yang menghasilkan 4 progeni } \\
\hline \multirow[t]{4}{*}{1} & $\mathrm{~F} 1-4 \mathrm{a}$ & TB-4 & TJ-198 & $2.76 \mathrm{E}+0$ & + \\
\hline & F1-146a & TB-146 & TJ-198 & $2.50 \mathrm{E}+0$ & + \\
\hline & F1-192e & TB-192 & TJ-198 & $2.17 \mathrm{E}-1$ & + \\
\hline & F1-197b & TB-197 & TJ-198 & $3.98 \mathrm{E}+0$ & + \\
\hline \multirow[t]{4}{*}{2} & $\mathrm{~F} 1-155 \mathrm{~b}$ & TB-155 & TJ-181 & $6.25 \mathrm{E}+0$ & $*$ \\
\hline & F1-11f & TB-11 & TJ-181 & $4.53 \mathrm{E}+0$ & + \\
\hline & F1-40e & TB-40 & TJ-181 & $2.96 \mathrm{E}+0$ & + \\
\hline & F1-175c & TB-175 & TJ-181 & $1.49 \mathrm{E}+0$ & + \\
\hline \multirow[t]{4}{*}{3} & F1-197a & TB-197 & TJ-202 & $-1.53 \mathrm{E}+0$ & + \\
\hline & F1-197d & TB-197 & TJ-202 & $2.98 \mathrm{E}+0$ & + \\
\hline & F1-197e & TB-197 & TJ-202 & $3.40 \mathrm{E}+0$ & + \\
\hline & F1-217a & TB-217 & TJ-202 & $2.11 \mathrm{E}+0$ & + \\
\hline \multicolumn{6}{|c|}{ Tetua jantan yang menghasilkan 5 progeni } \\
\hline \multirow[t]{5}{*}{1} & F1-91b & TB-91 & TJ-197 & $3.44 \mathrm{E}+0$ & + \\
\hline & $F 1-213 b$ & TB-213 & TJ-197 & $3.87 \mathrm{E}+0$ & + \\
\hline & $F 1-219 b$ & TB-219 & TJ-197 & $3.20 \mathrm{E}+0$ & + \\
\hline & $\mathrm{F} 1-255 \mathrm{~b}$ & TB-255 & TJ-197 & $3.69 \mathrm{E}+0$ & + \\
\hline & $\mathrm{F} 1-270 \mathrm{~b}$ & TB-270 & TJ-197 & $3.68 \mathrm{E}+0$ & + \\
\hline
\end{tabular}

Keterangan: TB = tetua betina; TJ = tetua jantan; ID = identitas; * = sangat nyata pada taraf $95 \%$; + = nyata pada taraf $80 \%$ 
Pendugaan nilai daya gabung khusus dan pendugaan pengaruh inbreeding terhadap sifat kuantitas endosperma belum bisa dilakukan pada studi ini, hal ini disebabkan karena terbatasnya data yang diperoleh sebagai akibat tidak diperolehnya data ulangan suatu persilangan spesifik. Hasil penelitian ini meskipun tidak diperoleh data ulangan persilangan spesifik, namun telah menunjukkan bahwa pendekatan polycross yang dikombinasikan dengan marka molekuler SSR berhasil membuat pendekatan polycross menjadi lebih baik karena tetua donor serbuk sarinya dapat diidentifikasi.

Tabel 3 menyajikan nilai skor kuantitas endosperma dari 28 kombinasi persilangan yang melibatkan 10 tetua donor serbuk sari dan 22 tetua betina. Pendugaan nilai daya gabung umum masing-masing tetua jantan dihitung dari selisih rataan masing-masing keturunan terhadap rataan umum (Acquaah, 2012). Tabel 3 memperlihatkan bahwa tetua jantan yang memiliki nilai daya gabung umum tertinggi adalah pohon tetua TJ-185 (3.36), sedangkan yang memiliki daya gabung umum terendah adalah pohon tetua TJ-130 (-1.64) dan TJ-15 (-1.64). Berdasarkan nilai daya gabung umumnya maka tetua TJ-185 dapat dinyatakan sebagai donor serbuk sari yang baik untuk sifat kuantitas endosperma kopyor. Hasil penelitian ini diharapkan dapat berkontribusi dalam upaya percepatan pengembangan kelapa kopyor unggul, yang sejak tahun 2012 telah mulai dirintis oleh Balit Palma Manado dan Institut Pertanian Bogor (Maskromo et al., 2012a, 2012b; Novarianto et al. 2014).

Tabel 3. Nilai dugaan daya gabung umum tetua donor serbuk sari

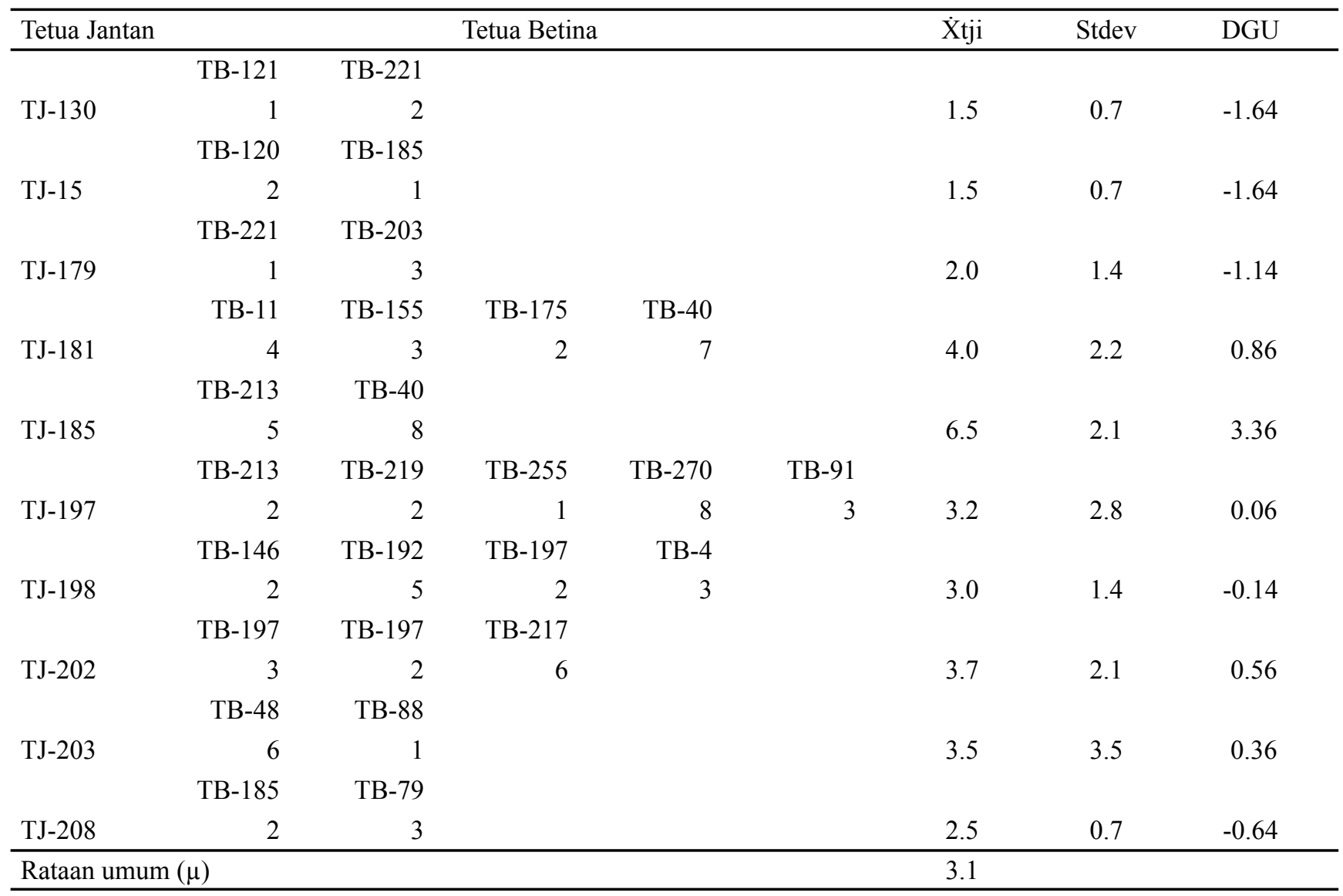

Keterangan: $\mathrm{TJ}=$ tetua betina; $\mathrm{TB}=$ tetua jantan; $1-8=$ nilai skor kuantitas endosperma buah kopyor hasil persilangan tetua jantan dan tetua betina tertentu; $\dot{X} \mathrm{tji}=$ rataan sampel skor endosperma individu tetua jantan; $\mu=$ rataan umum skor endosperma; Stdev $=$ simpangan baku; Nilai dugaan daya gabung umum $(\mathrm{DGU})=\dot{\mathrm{X}} \mathrm{tj} \mathrm{i}-\mu$

\section{KESIMPULAN}

Populasi kelapa kopyor Agom Lampung merupakan populasi menyerbuk silang dengan tingkat heterosigozitas yang tinggi dan merupakan sumber plasma nutfah penting bagi upaya pengembangan kelapa Dalam kopyor. Paternal analysis berbasis marka molekuler SSR dengan pendekatan polycross telah berhasil mengidentifikasi tetua jantan dan menduga nilai daya gabung umum tetua jantan donor serbuk sari untuk sifat kuantitas endosperma. Di antara tetua jantan yang telah berhasil diidentifikasi, pohon TJ-185 terseleksi sebagai pohon tetua jantan yang berpotensi baik guna perbaikan sifat kuantitas endosperma kelapa kopyor. 


\section{DAFTAR PUSTAKA}

Acquaah, G. 2012. Principle of Plant Genetics and Breeding. $2^{\text {nd }}$ ed. Wiley-Blackwell, Oxford, GB.

Ajambang, W., Sudarsono, D. Asmono, N. Toruan. 2012. Microsatellite markers reveal Cameroon's wild oil palm population as a possible solution to broaden the genetic base in the Indonesia-Malaysia oil palm breeding programs. Afric. J. Biotech. 11:1324413249 .

Brody, J.R., E. Kern. 2004. History and principles of conductive media for standard DNA electrophoresis. Analytical Biochemistry 333:1-13.

Budiman, L.F., A. Apriyanto, A. Pancoro, S. Sudarsono. 2019. Genetic diversity analysis of Tenera $\times$ Tenera and Tenera $\times$ Pisifera Crosses and D self of oil palm (Elaeis guineensis) parental populations originating from Cameroon. Biodiversitas 20:937-949.

Creste, S., A.T. Neto, A. Figueira. 2001. Detection of single sequence repeat polymorphism in denaturing polyacrylamide sequencing gels by silver staining. Plant Mol. Biol. Rep. 19:299-306.

Gunn, B.F., F Baudouin, K.M. Olsen. 2011. Independent origins of cultivated coconut (Cocos nucifera L.) in the old world tropics. Plos One 6:e2114.

Kalinowski, S.T., M.L.Taper, T.C. Marshall. 2007. Revising how the computer program CERVUS accommodates genotyping error increases success in paternity assignment. Mol. Ecol. 16:1099-1106. DOI: org/10.1111/j.1365-294x.2007.03089.x.

Kumar, K.D., R.K. Gautam, I. Ahmad, D.S. Roy, A. Sharma. 2015. Biochemical, genetic, and molecular basis of the novel and commercially important soft endosperm makapuno coconut a review. J. Food Agric. Environ. 13:61-65.

Larekeng, S.H., I. Maskromo, A. Purwito, N.A. Mattjik, S. Sudarsono. 2015. Pollen Dispersal and Pollination Patterns Studies in Pati Kopyor Coconut Using Molecular Markers. Int. J. Coconut Res. Dev. (CORD) 31:46-60.

Larekeng, S.H., I. Maskromo, A. Purwito, N.A. Matjik, Sudarsono. 2015. Penyebaran polen berdasarkan analisis SSR membuktikan penyerbukan kelapa Dalam Kalianda Normal ke Kopyor. Buletin Palma 16:77-92.
Lebrun, P., L. Baudouin, R. Bourdeix, J.L. Konan, J.H. Barker, C. Aldam, A. Herran, E. Ritter. 2001. Construction of a linkage map of the Rennell Island Tall coconut type (Cocos nucifera L.) and QTL analysis for yield characters. Genome 44:962-970.

Li, D., Y. Zheng, L. Wan, X. Zhu, Z. Wang. 2009. Differentially expressed microRNAs during solid endosperm development in coconut (Cocos nucifera L.). Sci. Hort. 122:666-669.

Martinez, T.R., L. Baudoin, A. Berger, M. Dollet. 2010. Characterization of genetic diversity of tall coconut (Cocos nucifera L.) in the Dominican Republic using microsatellite (SSR) marker. Tree Genet. Genomes $6: 73-81$

Maskromo, I., H. Novarianto, S. Sukendah, D. Sukma, S. Sudarsono. 2014. Keragaman komponen buah dan kualitas endosperma kelapa Dalam kopyor Kalianda dan kelapa Genjah kopyor Pati. Bul. Palma 15:102109.

Maskromo I., H. Novarianto, Sukendah, D. Sukma, Sudarsono. 2013. Productivity of three Dwarf kopyor coconut varieties from Pati, Central Java, Indonesia. Int. J. Coconut Res. Dev. (CORD) 29:19-28.

Maskromo, I., Sudarsono, H. Novarianto. 2012. Potensi produksi pohon induk kelapa dalam Kopyor asal Kalianda, Lampung Selatan. hal. 430-436. Dalam Prosiding Simposium dan Seminar Bersama PERAGI-PERHORTI-PERIPI-HIGI. Bogor 17-18 September 2012.

Maskromo, I., H. Novarianto, D. Sukma, Sudarsono. 2012. Potensi hasil plasma nutfah kelapa Kopyor asal Kalianda, Pati, Sumenep dan Jember. hal. 499-506. Dalam Prosiding Seminar nasional Pemanfaatan SDG Lokal Mendukung Industri Perbenihan Nasional. Bandung 17-18 Juni 2012.

Maskromo, I., E. T. Tenda, M. A. Tulalo, H. Novarianto, Sukendah, D. Sukma, S. Sudarsono 2015. Keragaman fenotipe dan genetik tiga varietas kelapa Genjah kopyor asal Pati, Jawa Tengah. J. Littri. 21:1-8.

Maskromo, I. 2015. Karakterisasi dan pemanfaatan plasma nutfah melalui pendekatan pemuliaan dan molekuler untuk peningkatan hasil buah kopyor dan kualitas benih kopyor. Disertasi. Sekolah Pascasarjana. Institut Pertanian Bogor. Bogor. 
Maskromo I, S.H. Larekeng, H. Novarianto, S. Sudarsono. 2016. Xenia Negatively Affecting Kopyor Nut Yield in Kalianda Tall Kopyor and Pati Dwarf Kopyor Coconuts. Emir. J. Food Agric. 28:644-652.

Natawijaya, A., S.W. Ardie, M. Syukur, I. Maskromo, A. Hartana, S. Sudarsono. 2019. Genetic structure and diversity between and within African and American oil palm species based on microsatellite markers. Biodiversitas 20:1233-1240.

Novarianto, H., I. Maskromo, D. Dinarti, S. Sudarsono. 2014. Production technology for kopyor coconut seednuts and seedlings in Indonesia. Int. J. Coconut Res. Dev. 30:31-40.

Olfati, J.A., Z. Sheykhtaher, R. Qamgosar, A.K. Sabet, G. Peyvast, H. Samizadeh, B. Rabiee. 2010. Xenia and metaxenia on cucumber fruit and seed characteristics. Int. J. Veg. Sci. 16:243-252.

Pandin, D.S., A. Hartana, H. Aswidinnoor, A. Setiawan. 2008. Pelacakan tetua populasi kelapa dalam Mapanget No.32 (DMT-32) menggunakan analisis aliran gen (gene flow). J. Littri. 14:131-140.

Pandin DS. 2009. Inbreeding depression analysis based on morphological characters in four generations of selfed Mapanget Tall Coconut no 32 (Cocos nucifera L.). Indonesian J. Agric. 2:110-114.

Perera, P.I.P., V. Hocher, L.K. Weerakoon, D.M.D. Yakandawala, S.C. Fernando, J.L. Verdeil. 2010. Early inflorescence and floral development in Cocos nucifera L. (Arecaceae: Arecoideae). S. Afr. J. Bot. 76:482-492.

Pesik, A., D. Efendi, H. Novarianto, D. Dinarti, S. Sudarsono. 2017. Development of SNAP markers based on nucleotide variability of WRKY genes in coconut and their validation using multiplex PCR. Biodiversitas 18:465-475.

Pesik, A., D. Efendi, H. Novarianto, D. Dinarty, I. Maskromo, E.T. Tenda, Sudarsono. 2015. Keragaman dan Hubungan Genetik Antara Kelapa Tetua Genjah Kuning Nias. Bulletin Palma 16:129-140.

Ribeiro, F.E., L. Baodouin, P. Lebrun, L.J. Chaves, C. Brondani, M.I. Zucchi, R. Vencovsky. 2010. Population structures of Brazillian Tall Coconut (Cocos nucifera L.) by microsatellite markers. Genet. Mol. Biol. 33:696-102.

Rohde, W., A. Kullaya, J. Rodriguez, E. Ritter. 1995. Genome analysis of Cocos nucifera L. by PCR ampliification of spacer sequences separating a subset of copies-like EcoR1 repetitive elements. J. Genet. Breed. 49:170186.

Sudarsono, I. Maskromo, D. Dinarti, M.S. Rahayu, D. Sukma, Yuliasti, M.L.A. Hossang, H. Novarianto. 2015. Status penelitian dan pengembangan kelapa kopyor di Indonesia. hal. 53-64. Dalam Prosiding Konferensi Nasional Kelapa (KNK) VIII, Bengkulu.

Sudarsono, H. Novarianto, I. Maskromo. 2011. Diversity of endosperm quantity among Kalianda Tall coconut. p. 27-28 In Prosiding of International Seminar on Natural Resources, Climate Change, and Food Security (ISNAR C2FS), Surabaya, Indonesia.

Sudarsono. 2017. From (Land-To) Lab-To Land: Menjawab Permasalahan dan Mengembangkan Potensi Kelapa Kopyor Indonesia. Dalam Landasan Teoritis dan Penerapan Genetika serta Rekayasa Lingkungan untuk Peningkatan Produksi Tanaman. IPB Press, Bogor, Indonesia

Sukendah, S., H. Volkaerd, S. Sudarsono. 2017. Isolation and Analysis of Sucrose Synthase (SUS) Gene Fragment Originated from "Kopyor" Coconut Mutant. Adv. Sci. Lett. 23:12223-12226.

Sukendah, H Volkaert, Sudarsono. 2009. Isolation and analysis of DNA fragment of genes related to Kopyor trait in coconut plants. Indonesian J. Biotechnol. 14:1169-1178.

Tew, T., Y.B. Pan. 2010. Microsattelite (Simple sequence repeat) marker based paternity analysis of a sevenparent sugarcane polycross. Crop Sci. 50:14011408 .

Tinche, D. Asmono, D. Dinarti, Sudarsono. 2014. Keragaman genetik kelapa sawit (Elaeis guineensis Jacq.) populasi Nigeria berdasarkan analisis marka SSR (Simple Sequence Repeat). Buletin Palma 15:14-23.

Yao, S.D.M., K.J.L. Konan, N.D. Pokou, K.J.N. Konan, A.E. Assali, R.S. Sie, B.I.A. Zoro. 2013. Assessment of the genetic diversity conservation in three tall coconut (Cocos nucifera L.) accessions regenerated by controlled pollination, using microsatellite markers. Afr. J. Biotechnol. 12:2808-2815.

Yono, D., Y. Wahyu, Sobir, N. Toruan-Mathius. 2017. Identifikasi penanda SSR yang berasosiasi dengan bobot tandan buah kelapa sawit (Elaeis guineensis Jacq.). J. Agron. Indonesia 45:79-85. 